\title{
Granulomatous myelitis associated with hemorrhagic syndrome due to consumption of Vicia villosa by cattle
}

\author{
Mielite granulomatosa associada à síndrome hemorrágica devido ao consumo de \\ Vicia villosa em um bovino
}

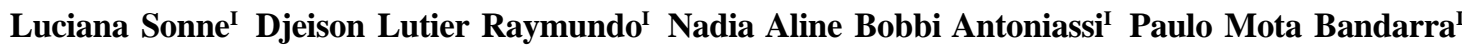 Paula Rodrigues de Almeida ${ }^{I}$ Itabajara da Silva Vaz Júnior ${ }^{I I}$ David Driemeier $^{{ }^{*}}$}

- NOTE -

\section{ABSTRACT}

An unusual case of spontaneous Vicia villosa poisoning affected a 6-year-old Holstein cow. Although the most striking findings included a generalized hemorrhagic condition associated with granulomatous myelitis, histological lesions typically seen with the vetch-associated systemic granulomatous syndrome were also present. Prominent gross findings were bloody nasal and oral discharges, disseminated hemorrhages, and bloody feces. Generalized hemorrhages associated with infiltration of numerous organs by lymphocytes, plasma cells, macrophages, multinucleated giants cells, and eosinophils were the main microscopic findings. Anti-CD68 immunostaining confirmed the presence of moderate histiocytic infiltrate and multinucleated giant cells in the bone marrow. These changes in the bone marrow probably caused the generalized hemorrhagic changes described here.
\end{abstract}

Key words: plant poisoning, cattle, Vicia villosa, hemorrhagic disease, granulomatous inflammation.

\section{RESUMO}

Um bovino Holandês de seis anos naturalmente intoxicado pela Vicia villosa apresentou lesões não comumente encontradas nessa intoxicação. Embora a lesão mais evidente fosse hemorragia generalizada associada à mielite granulomatosa, as lesões granulomatosas típicas da intoxicação pela ervilhaca também estavam presentes histologicamente. Os principais achados macroscópicos foram hemorragias nasal e oral, hemorragias generalizadas e fezes com sangue. Lesões hemorrágicas generalizadas associadas com infiltrado inflamatório de linfócitos, plasmócitos, macrófagos, células gigantes multinucleadas e eosinófilos foram os principais achados microscópicos encontrados. $O$ teste imuno-histoquímico anti-CD68 confirmou a presença de infiltrado moderado de macrófagos e de células gigantes multinucleadas na medula óssea. As alterações na medula óssea provavelmente constituem a causa da hemorragia generalizada descrita nesse caso.

Palavras-chave: intoxicação por planta, bovino, Vicia villosa, doença hemorrágica, inflamação granulomatosa.

Vicia villosa (hairy vetch) has been used as source of forage for livestock in countries with temperate or subtropical climates (PANCIERA et al., 1992; BARROS et al., 2001; RIET-CORREA et al., 2007). Nevertheless, poisoning by hairy vetch has been described in horses (ANDERSON \& DIVERS, 1983; WOODS et al., 1992) and cattle (PANCIERA et al., 1966; ODRIOZOLA et al., 1991; JOHNSON et al., 1992; HARPER et al., 1993; BARROS et al., 2001). Although it has also been linked to other syndromes (CLAUGHTON \& CLAUGHTON, 1954), hairy vetch poisoning most commonly manifests as an untreatable systemic granulomatous condition, the clinical signs of which may include dermatitis, conjunctivitis, pruritus, diarrhea, wasting, and death (PANCIERA et al., 1966; PANCIERA et al., 1992). The main gross changes are alopecic areas, papules, exudation, and crusts in the skin and white or gray nodules in

'Departamento de Patologia Clínica Veterinária, Faculdade de Medicina Veterinária, Universidade Federal do Rio Grande do Sul (UFRGS), Av. Bento Gonçalves 9090, 91540-000, Porto Alegre, RS, Brasil. E-mail: davetpat@ufrgs.br *Autor para correspondência. IIFaculdade de Veterinária, UFRGS, Porto Alegre, RS, Brasil. 
numerous organs (PANCIERA et al., 1966; JOHNSON et al., 1992; PANCIERA et al.,1992; BARROS et al., 2001). Typical histological findings in vetch-associated disease include infiltration of skin and numerous organs by macrophages, lymphocytes, plasma cells, multinucleated giants cells and eosinophils (PANCIERA et al., 1966; PANCIERA et al., 1992; RIETCORREA et al., 2007). This report describes an unusual bovine case of hairy vetch poisoning characterized by a generalized hemorrhagic condition associated with granulomatous myelitis.

The poisoning occurred in a 6-year-old Holstein cow from a small dairy herd (14 lactating cows) located in the northwest region of Rio Grande do Sul, Brazil. The cows had been grazing on pastures composed of Vicia villosa and ryegrass (Lolium sp.) for approximately 120 days. Animals were also supplemented with corn silage and commercial concentrate. The affected cow remained ill for 12 days before dying, and clinical signs included weight loss, decreased milk production, alopecia, and formation of crusts mainly in the face (Figure 1A). Upon necropsy, the most remarkable findings were large amounts of bloody nasal and oral discharges, and disseminated hemorrhages, which were most prominent in the urinary bladder (Figure 1B), kidneys (Figure 1C), heart, and subcutaneous tissues, but were also observed in the omentum, adrenal gland, lungs, liver, and small intestine. Additional gross changes included bloody feces, enlarged lymph nodes, multiple whitish nodules in the cut surface of several lymph nodes, and splenomegaly. Tissue samples were collected, formalin fixed, and processed for routine histology. Microscopically, hemorrhages associated with infiltration by lymphocytes, macrophages and multinucleated giant cells were disseminated in numerous organs and tissues, especially in the kidneys (Figure 1D), heart, lymph nodes, skeletal muscle, lung, and spleen. The latter tissue also had hemosiderosis. Orthokeratotic hyperkeratosis and mixed inflammatory cell infiltration (lymphocytes, plasma cells, macrophages, multinucleated giants cells, and eosinophils) were observed in the skin of the face and ears. Brain vessels were cuffed by epithelioid macrophages, plasma cells, and lymphocytes. The liver had multifocal hemorrhage, mild paracentral necrosis, and mild periportal inflammatory infiltrate associated with fibrosis. In the rib bone marrow, there were moderate numbers of macrophages and multinucleated giant cells (Figure 1E) that replaced hematopoietic cell precursors and adipocytes. Remaining precursor cells were mostly from granulocytic lineage, specifically of the eosinophilic cell line. Most eosinophil precursors were in the myelocyte stage, but there also were a few metamyelocytes and rod-shape eosinophils. Both immature and mature populations of neutrophils were scarce. Erythron was markedly enhanced, which diminished the myeloid to erythroid ratio to approximately 0.2:1 (bovine normal range 0.44-0.52:1 JAIN, 1986). Lymphoid and megakaryocytic populations were normal and there were no morphological alterations in any of the bone marrow cells.

No microorganisms were detected in hematoxylin-eosin(HE) or Ziehl-Neelsen stained sections. Anti-CD68 (Dako) immunostaining (dilution 1:100/ streptavidin-biotin peroxidase/3,3-diaminobenzidineDako) showed characteristic brown staining within the monocytes/macrophages and multinucleated giants cells in rib bone marrow sections (Figure 1F).

While the findings typically observed in vetch-associated systemic granulomatosis in cattle were also present in this case, an unusual but pronounced hemorrhagic condition was the most striking finding observed here. Hemorrhagic changes associated with Vicia villosa poisoning in cattle have rarely been observed previously (PEET \& GARDNER, 1986; ODRIOZOLA et al., 1991). Comparable hemorrhagic disease has been observed in cases of ingestion of citrus pulp (SAUNDERS et al., 2000; IIZUKA et al., 2005; GAVA \& BARROS, 2007), silage made with the additive Sylade (MATTHEWS \& SHREEVE, 1978; MORRIS \& MCINNES, 1978) and concentrate with di-ureido-isobutane (DUIB) (BREUKINK et al., 1978). The diet of this affected cow included neither Sylade-added silage, concentrate with DUIB, nor citrus pulp. Acute poisoning by bracken fern (Pteridium aquilinum) may also produce a similar hemorrhagic disease, but distinctive changes in bone marrow consist of aplasia associated with accentuated decrease in the erythroid, myeloid and megakaryocytic populations (TOKARNIA et al., 2002), in addition to epidemiologic information about the presence of the plant. The cause of the hemorrhage in poisoning by silage containing Sylade has not been elucidated (MATTHEWS \& SHREEVE, 1978; MORRIS \& MCINNES, 1978); however, these authors had not analyzed the bone marrow of the affected animals. The hemorrhages observed in citrus pulp poisoning have been linked to the replacement of normal tissues in bone marrow by granulomatous inflammatory obliteration with resultant thrombocytopenia (GAVA \& BARROS, 2007). FIGHERA \& BARROS (2004) observed no granulomatous inflammatory infiltrates in the bone marrow of the six vetch-intoxicated cattle from which this tissue was examined, but those animals 


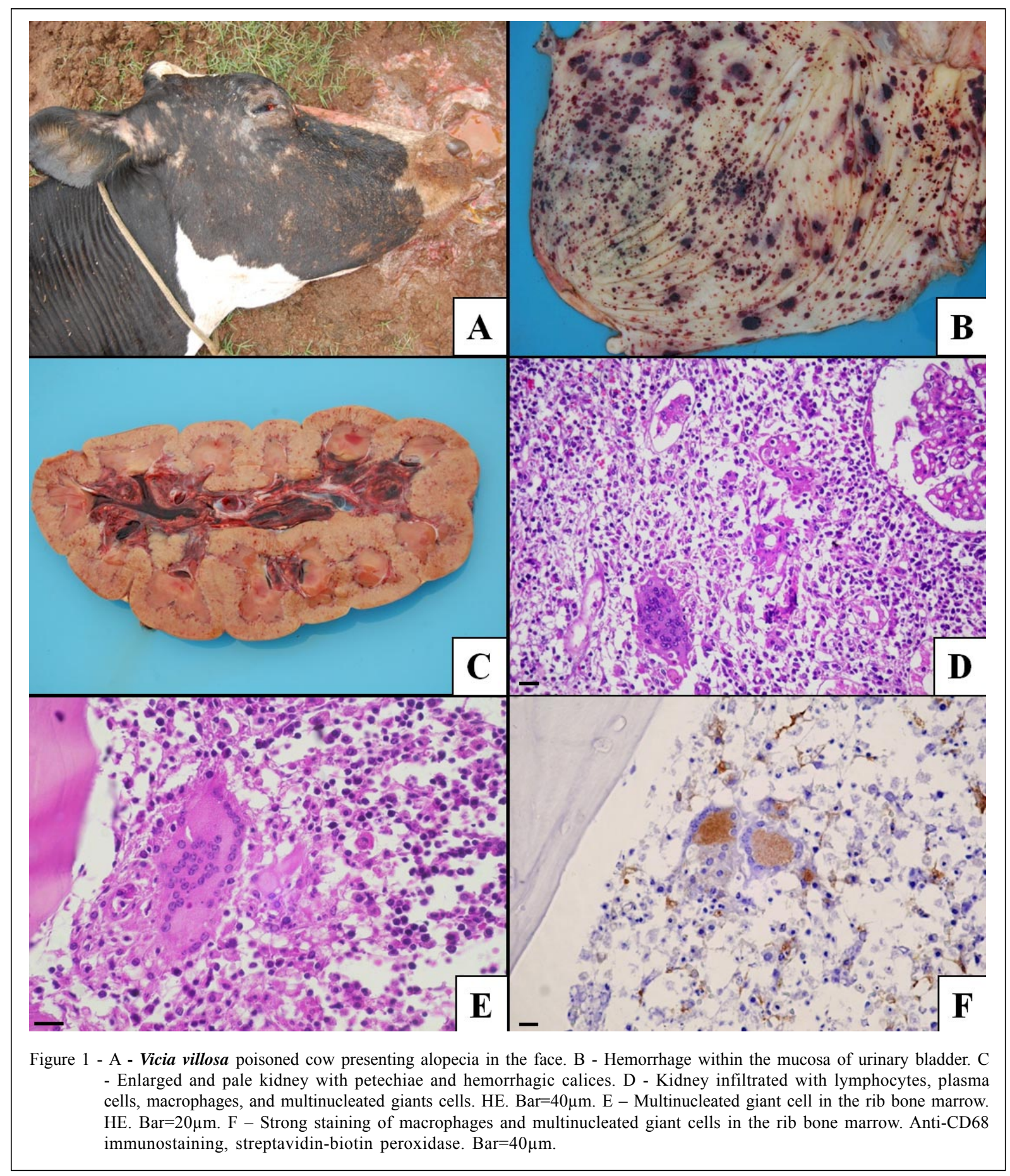

did not have either a hemorrhagic disease as the cow in this case, which had changes in the bone marrow typical of myelophthisis secondary to the granulomatous myelitis. Although thrombocytopenia would have been a possible explanation for the disseminated hemorrhages in this case, thrombocytopenia could not be proven because it is not possible to determine the platelet count in a dead cow. In general, widespread hemorrhages may also be secondary to acute liver damage due to excessive consumption of coagulation factors at the site of the necrotic insult as well as due to inability of the liver to further synthesize coagulation factors (STALKER \& HAYES, 2007). In the present case, the liver

Ciência Rural, v.40, n.8, ago, 2010. 
parenchyma maintained considerable integrity and showed only mild changes, which included paracentral necrosis, a known consequence of anemic processes (CULLEN, 2007). This strengthens the hypothesis that the hemorrhages in this cow are attributed to the changes in the bone marrow. The findings described here therefore suggest that hemorrhages linked to hairy vetch poisoning may be caused by myelophthisis secondary to histiocytic infiltration in the bone marrow. To further confirm this hypothesis, it is essential that bone marrow is included in the set of tissue samples to be collected and examined histologically in cases of hemorrhagic diathesis in cows grazing on pastures containing hairy vetch.

\section{ACKNOWLEDGMENT}

Authors are grateful to professor Rafael Fighera (UFSM) for histologic bone marrow evaluation and to professor Cláudio Estêvão Farias Cruz for reviewing this manuscript. This work was supported by grant from CNPq-Brazil.

\section{REFERENCES}

ANDERSON, C.A.; DIVERS, T.J. Systemic granulomatous inflammation in a horse grazing hairy vetch. Journal of the American Veterinary Medical Association, v.183, p.569$570,1983$.

BARROS, C.S.L. et al. Doença granulomatosa sistêmica em bovinos no Rio Grande do Sul associada ao pastoreio de ervilhaca (Vicia spp). Pesquisa Veterinaria Brasileira, v.21, p.162171, 2001. Available on: <http://www.scielo.br/ scielo.php? script=s ci arttext\&pid=S $0100-$ 736X2004000300010>. Accessed: Abr. 22, 2010 . doi: $10.1590 / \mathrm{S} 0100-736 \mathrm{X} 2004000300010$

BREUKINK, H.J. et al. Pyrexia with dermatitis in dairy cows. Veterinary Record, v.2, p.221-222, 1978.

ClAUGHTON, W.P.; CLAUGHTON, H.D. Vetch seed poisoning. Auburn Veterinarian, v.10, p.125-126, 1954.

CULLEN, J.M. Liver, biliary system, and exocrine pancreas. In: MCGAVIN, M.D.; ZACHARY, J.F. Pathologic basis of veterinary disease. 4.ed. St. Louis: Mosby Elsevier, 2007. Cap.8, p.393-461.

FIGHERA, R.A.; BARROS, C.S.L. Systemic granulomatous disease in Brazilian cattle grazing pasture containing vetch (Vicia spp). Veterinary and Human Toxicology, v.46, n.2, p.62-66, 2004

GAVA, A.; BARROS, C.S.L. Intoxicação por polpa cítrica. In: RIET-CORREA F. et al. Doença de ruminantes e eqüídeos. 3.ed. Santa Maria: Pallotti, 2007. p.90-94.
HARPER, P. et al. Vetch toxicosis in cattle grazing Vicia villosa spp. dasycarpa and V. benghalensis. Australian Veterinary Journal, v.70, p.140-144, 1993

IIZUKA, A. et al. An outbreak of systemic granulomatous disease in cows with high milk yields. Journal Veterinary Medicine Science, v.67, p.693-699, 2005.

JAIN, N.C. Schalm's veterinary hematology. 4.ed. Philadelphia: Lea \& Febiger, 1986. 1221p.

JOHNSON, B. et al. Systemic granulomatous disease in cattle in California associated with grazing hairy vetch (Vicia villosa). Journal of Veterinary Diagnostic Investigation, v.4, p.360-362, 1992 .

MATTHEWS, J.G.; SHREEVE, B.J. Pyrexia/pruritus/ haemorrhagic syndrome in dairy cows. Veterinary Record v.28, p.408, 1978 .

MORRIS, J.; MCINNES, I.J. Pyrexia with dermatitis in dairy cows. Veterinary Record, v.22, p.368, 1978.

ODRIOZOLA, E. et al. An outbreak of Vicia villosa (hairy vetch) poisoning in grazing Aberdeen Angus Bulls in Argentina. Veterinary and Human Toxicology, v.33, p.278-280, 1991.

PANCIERA, R.J. et al. A disease of cattle grazing hairy vetch pasture. Journal of the American Veterinary Medical Association, v.148, p.804-808, 1966.

PANCIERA, R.J. et al. Hairy vetch (Vicia villosa Rotch) poisoning in cattle: update and experimental induction of disease. Journal of Veterinary Diagnostic Investigation, v.4, p.318-325, 1992

PEET, R.L.; GARDNER, J.J. Poisoning of cattle by hairy or woolly-pod vetch, Vicia villosa subspecies dasycarpa. Australian Veterinary Journal, v.63, p.381-382, 1986.

RIET-CORREA, F. et al. Plantas e micotoxinas que afetam a pele e outros órgãos. In: RIET-CORREA, F. et al. Doenças de ruminantes e eqüídeos. 3.ed. Santa Maria: Pallotti, 2007. p.209-211.

SAUNDERS, G.K. et al. Suspected citrus pulp toxicosis in dairy cattle. Journal of Veterinary Diagnostic Investigation, v.12, p.269-271, 2000.

STALKER, M.J.; HAYES, M.A. Liver and biliary system. In MAXIE, M.G. Jubb, Kennedy, and Palmer's pathology of domestic animals. Philadelphia: Elsevier, 2007. p.297381 .

TOKARNIA, C.H., et al. Poisonous plants affecting livestock in Brazil. Toxicon, v.40, p.1635-1660, 2002.

WOODS, L.W. et al. Systemic granulomatous disease in a horse grazing pasture containing vetch (Vicia sp.). Journal of Veterinary Diagnostic Investigation, v.4, p.356-360, 1992. 